\title{
Factors Related to Adolescent Behavior in HIV/AIDS Prevention
}

\section{Faktor-Faktor yang Memengaruhi Perilaku Remaja terhadap Pencegahan HIV/AIDS}

\author{
Ratyas Ekartika Puspita Candra Nugrahawati*, Munica Rita Hernayanti*,Yuliasti Eka Purnamaningrum*, Vajee \\ Petphong**
}

\begin{abstract}
*Health Polytechnic Yogyakarta, Indonesia, **Faculty of Tropical Medicine Department of Microbiology and Immunology, Mahidol University
\end{abstract}

\begin{abstract}
In 2016, the Special Region of Yogyakarta ranked 9th as the province with the highest number of people suffering from HIVIAIDS, especially in the Sleman District. Globally, AIDS is the second leading cause of death in adolescents aged 10-19 years. This study to aimed out factors affecting the behavior of adolescents toward HIVIAIDS prevention. This study used a cross-sectional study design. The sampling technique used was stratified random sampling that resulted in 59 respondents from 11th-grade students at Sleman 2 Senior High School who were selected as samples. Data were collected using a questionnaire and analyzed using Chi-square test and multiple logistic regression. The results showed that most respondents $66.1 \%$ had sufficient knowledge. More than a half $(54.2 \%)$ of students showed supportive attitude. Information was mostly obtained from electronic media. Thirty-one students (52.5\%) showed a positive attitude toward HIVIAIDS prevention. Chi-square test result showed that factors significantly related to adolescent's behavior toward HIVIAIDS prevention were knowledge and attitude. The most influential variable was attitude ( $\mathrm{p}$-value $=0.008 ; \mathrm{PR}=4.4 ; 95 \% \mathrm{Cl}=1.4-13.1)$.
\end{abstract}

Keywords: Adolescent, attitude, behavior, HIVIAIDS prevention

\begin{abstract}
Abstrak
Daerah Istimewa Yogyakarta pada tahun 2016 menempati urutan ke-9 sebagai provinsi dengan penderita HIV/AIDS terbanyak dan tertinggi diduduki Kabupaten Sleman. Secara global, AIDS merupakan penyebab kematian kedua pada remaja umur 10-19 tahun. Tujuan penelitian ini untuk mengetahui faktor-faktor yang mempengaruhi perilaku remaja terhadap pencegahan HIVIAIDS. Penelitian ini menggunakan metode survei analitik dengan desain potong lintang. Teknik sampling stratified random sampling dengan jumlah sampel 59 responden kelas XI di Senior High School 2 Sleman. Instrumen penelitian berupa kuesioner dan dianalisis secara univariat, bivariat, dan multivariat menggunakan uji Chi-square dan regresi logistik. Hasil penelitian menyatakan bahwa pengetahuan tentang HIVIAIDS terbanyak pada kategori cukup, 66,1\% responden. Sikap terhadap pencegahan HIVIAIDS terbanyak pada kategori mendukung, 54,2\% responden. Sumber informasi mayoritas diperoleh dari media elektronik sebanyak 49,2\%. Perilaku terhadap pencegahan HIVIAIDS terbanyak pada kategori positif, 52,5\% responden. Hasil uji Chi-square faktor yang berhubungan secara signifikan dengan perilaku remaja terhadap pencegahan HIVIAIDS adalah tingkat pengetahuan dan sikap. Faktor yang paling mempengaruhi perilaku remaja terhadap pencegahan HIVIAIDS adalah sikap (nilai $p=0,008 ; P R=4,4 ; \mathrm{Cl} 95 \%=1,4-13,1$ ).
\end{abstract}

Kata kunci: Remaja, sikap, perilaku, pencegahan HIVIAIDS

How to Cite: Nugrahawati REPC, Hernayanti MR, Purnamaningrum YE, Petphong V. Factors related to adolescent behavior in HIVIAIDS prevention. Kesmas: National Public Health Journal. 2019; 13 (4): 197-203. (doi:10.21109/kesmas.v13i4.2698)
Correspondence: Yuliasti Eka Purnamaningrum, Jurusan Kebidanan Poltekkes Kemenkes Yogyakarta, Jl. Mangkuyudan MI III/304 Yogyakarta 55143, Phone: +62-81328223177, E-mail: yuliasti.eka.purnamaningrum@gmail.com Received : October $24^{\text {th }} 2018$

Revised : January $4^{\text {th }} 2019$

Accepted : March 28th 2019 


\section{Introduction}

Adolescence is a time of physical and mental development, which is also accompanied by sexual development. ${ }^{1}$ Adolescence is also to increasing sexual and reproductive health risks, including HIV/AIDS. ${ }^{2}$ Acquired immunodeficiency syndrome (AIDS) is a syndrome with opportunistic symptoms of infectious diseases or certain cancers due to a decrease in the immune system as a result of infection with the Human Immunodeficiency Virus (HIV). ${ }^{3}$

Based on UNAIDS data from 2014, 36.7 million people had contracted HIV by the end of 2016. An estimated $0.8 \%$ of people aged $15-49$ years worldwide live with HIV. One million people died from HIV-related diseases worldwide in $2016 .{ }^{4} \mathrm{~A}$ total of 19 million people worldwide do not know that their HIV status is positive. ${ }^{5}$ Globally, AIDS is the second leading cause of death in adolescents aged 10-19 years. The number of AIDSrelated deaths among 15-19 year olds has more than doubled since 2000. In 2015, there were 29 new infections found every hour in average between this age group worldwide. ${ }^{6}$

The number of HIV/AIDS cases fluctuates every year. By the end of 2016, the number of HIV/AIDS cases had increased, and the number of cases reported in Indonesia was 41,250 for HIV and 7,491 for AIDS. The number of AIDS cases reported was based on occupational group/status. From October to December 2016, 130 cases of AIDS were found among school children or students. This was almost the same number as sex workers. ${ }^{7}$ Special Province of Yogyakarta ranked 9th as the province with the most HIV/AIDS cases. In 2016, the most HIV/AIDS cases in this province were recorded in Sleman District, with 868 HIV and 352 AIDS cases. Based on sex, the HIV cases were 3,688. These cases consisted of 1,178 females; 2,429 males; and 81 cases in which the sex of the patient was unknown. HIV is mostly diagnosed in people aged $20-29$ years. ${ }^{8}$ The youngest age when infected is approximately $15-24$ years. ${ }^{9}$ This means that the patients had been infected with AIDS for five years.

The results of the Millennium Development Goals (MDGs) showed that the percentage of population aged 12-24 years who have comprehensive knowledge about HIV/AIDS is $67.3 \%$ for men and $66 \%$ for women. ${ }^{10}$ To achieve the MDGs target, Sustainable Development Goals was performed, and its results will be shown by 2030. This program is expected to end the epidemic of AIDS.11 Good knowledge will support good attitudes. Knowledge of HIV/AIDS can influence students to take precautions and make good choices. ${ }^{12}$ Adolescents with a positive attitude display good behavior. ${ }^{13}$ Attitudes reflect the level of knowledge of an individual. The Way someone behaves in response to certain events shows his/her knowledge's level on that matter. The adaptation theory states that the level of good knowledge can encourage an individual to have good behavior. ${ }^{14}$ Exposure to information sources in order to influence HIV/AIDS prevention behavior proves that the exposure to information sources is very influential in improving HIV/AIDS prevention. ${ }^{15}$ According to Heny, factors related to risky behavior in adolescents in Indonesia as found in the Indonesian Youth Reproductive Health Survey in 2007 were knowledge, attitude, age, sex, education, economic status, access to information media, communication with parents, and the friends who engage in risky behavior. 16

A preliminary study conducted at the Sleman District Health Office using observation and interviews found that the number of HIV/AIDS cases in Sleman District was $80 \%$. Based on case data based on occupation, the third highest case was found in students with 112 cases. Sleman 2 State Senior High School is located in Brayut Pandowoharjo, Sleman Subdistrict, Sleman District. This area is under the supervision of Sleman Health Center, which actively carries out HIV/AIDS prevention activities. These activities were conducted by school counselors. These activities support the government's program study on Youth Care Health Services. In addition, Sleman 2 State Senior High School also often receives counseling about adolescent health from the police. In its education curriculum, Sleman 2 State Senior High School has implemented education about HIV/AIDS in biology and physical education subjects (physical education, sports, and health). Sleman 2 State Senior High School also receives counseling about HIV/AIDS every year from Sleman Health Center during its Student Orientation Period. Counseling is one of the measures taken to prevent HIV/AIDS in adolescents. Therefore, we were interested in conducting a study on "Factors Affecting Adolescent Behavior on Prevention of HIV/AIDS in Sleman 2 State Senior High School in 2018." This study aimed to determine factors associated to adolescent behavior toward HIV/AIDS prevention among Senior High School 2 Sleman students.

\section{Method}

This study was cross-sectional, conducted at Sleman 2 State Senior High School. The study population includes the students of class XI in Sleman 2 State Senior High School. The study samples consisted of 59 respondents from the Natural Science and Social Sciences majors. Samples were taken by a stratified random sampling technique randomizing all classes of natural science and social studies majors. The independent variables in this study are characteristics (sex, major), level of knowledge, attitude, behavior, and sources of information. The dependent variable was the 
behavior of adolescents toward the prevention of HIV/AIDS. Primary data gathering was done using selfadministered questionnaires. Data were analyzed using univariate, bivariate with Chi-square test, and multivariate analysis with logistic regression. The levels of knowledge were categorized as good (the percentage of $76 \%-100 \%$ ), adequate (the percentage of $56 \%-$ $75 \%$ ), and low (percentage of $<56 \%$ ). Adolescent behaviors were categorized as positive (score, 15.14) and negative (score $<15.14$ ). Attitudes were categorized as support (score $\geq 74.83$ ) and does not support (score < 74.83). Multivariate analysis using logistic regression analysis was performed on variables that showed p-value $<0.25$ during bivariate analysis. In this study, the multivariate variables that can be analyzed are the level of knowledge $(p$-value $=0.035)$ and attitude $(p$-value $=$ 0.007). This study received a letter from the Ethics Committee of the Health Ministry of Yogyakarta, Number LB.01.01/KE-02/XVI/344/2018 dated April 24, 2018.

\section{Results}

The total number of respondents was 59 . The majority $(35 ; 59.3 \%)$ were female. A total of 32 respondents were majoring in natural sciences $(54.2 \%)$ and 27 in social sciences $(45.8 \%)$. The results showed that the majority of respondents $(39 ; 66.1 \%)$ had an adequate knowledge level about HIV/AIDS. Then 32 respondents (54.2\%) held supportive attitudes toward HIV/AIDS prevention. Respondents' sources of information about HIV/AIDS were electronic media $(29 ; 49.2 \%)$ respondents. A total $31(52.5 \%)$ had a positive attitude toward HIV/AIDS prevention (Table 1).

The results of the Chi-square test (Table 2) showed a significant relationship between the level of knowledge and attitudes toward the prevention of HIV/AIDS with $\mathrm{p}$-value $<0.05$. The variables of sex, education majors, and information sources indicate that there is no significant relationship with adolescent behavior toward HIV/AIDS prevention with p-value $>0.05$.

The results of the multivariate test analysis in Table 3 shows that statistically significant variables are attitudes with $\mathrm{p}$-value $=0.008 ; \mathrm{PR}=4.4 ; 95 \% \mathrm{CI}=1.4-13.1$; thus, adolescents who have an attitude toward the prevention of HIV/AIDS in the supporting category are 4.4 times more likely to show positive behavior than adolescents who have an unsupportive attitude toward HIV/AIDS prevention.

\section{Discussion}

Most of the respondents to this study were female $(59.3 \%)$ and majoring in natural science $(54.2 \%)$. The results of the study on the level of knowledge showed that the majority of respondents had an adequate knowledge level $(66.1 \%)$. Most respondents had a supportive attitude toward prevention of HIV/AIDS $(54.2 \%)$. Electronic media was the most popular source

Table 1. The Distribution of Respondents' Frequency based on Characteristics, Knowledge Level, Behavior, Sources of Information, and Attitude in Sleman 2 State Senior High School in 2018

\begin{tabular}{llrr}
\hline Characteristics & Category & n & $\%$ \\
\hline \multirow{2}{*}{ Sex } & Male & 24 & 40.7 \\
\multirow{2}{*}{ Major } & Female & 35 & 59.3 \\
\multirow{2}{*}{ Knowledge Level } & Natural sciences & 32 & 54.2 \\
& Social sciences & 27 & 45.8 \\
\multirow{3}{*}{ Behavior } & Good & 16 & 27.1 \\
\multirow{2}{*}{ Source of Information } & Adequate & 49 & 66.1 \\
& Low & 32 & 5.8 \\
\multirow{2}{*}{ Attitude } & Support & 27 & 45.8 \\
& Does not support & 13 & 22 \\
& Electronic media & 29 & 49.2 \\
& Direct & 17 & 28.8 \\
& Positive & 31 & 52.5 \\
& Negative & 28 & 47.5 \\
\hline
\end{tabular}

Table 2. The Results of Bivariate Analysis

\begin{tabular}{|c|c|c|c|c|c|c|c|c|}
\hline \multirow{3}{*}{ Variable } & \multirow{3}{*}{ Category } & \multicolumn{4}{|c|}{ Attitudes } & & & \multirow{3}{*}{ p-Value } \\
\hline & & \multicolumn{2}{|c|}{ Positive } & \multicolumn{2}{|c|}{ Negative } & \multicolumn{2}{|c|}{ Total } & \\
\hline & & f & $\%$ & f & $\%$ & f & $\%$ & \\
\hline \multirow[t]{2}{*}{ Sex } & Male & 11 & 45.83 & 13 & 54.16 & 24 & 100 & 0.393 \\
\hline & Female & 20 & 57.14 & 15 & 42.86 & 35 & 100 & \\
\hline \multirow[t]{2}{*}{ Major } & Natural sciences & 18 & 56.25 & 14 & 43.75 & 32 & 100 & 0.535 \\
\hline & Social sciences & 13 & 48.15 & 14 & 51.85 & 27 & 100 & \\
\hline \multirow[t]{2}{*}{ Knowledge Level } & Good & 12 & 75 & 4 & 25 & 16 & 100 & 0.035 \\
\hline & Adequate & 19 & 44.19 & 24 & 55.81 & 43 & 100 & \\
\hline \multirow[t]{2}{*}{ Behavior } & Support & 22 & 68.75 & 10 & 31.25 & 32 & 100 & 0.007 \\
\hline & Does not support & 9 & 33.33 & 18 & 66.67 & 27 & 100 & \\
\hline \multirow[t]{3}{*}{ Source of Information } & Printed media & 7 & 53.85 & 6 & 46.15 & 13 & 100 & 0.863 \\
\hline & Electronic media & 16 & 55.17 & 13 & 44.83 & 29 & 100 & \\
\hline & Direct & 8 & 47.06 & 9 & 52.94 & 17 & 100 & \\
\hline
\end{tabular}


Table 3. The result of Multivariate Analysis

\begin{tabular}{lccccccccc}
\hline & B & S.E & Wald & df & Sig. & $\operatorname{Exp}(\mathbf{B})$ & & \multicolumn{2}{c}{$\mathbf{9 5 \% \mathbf { C I } \text { for } \mathbf { E X P } ( \mathbf { B } )}$} \\
\cline { 6 - 9 } & & & & & & & Lower & Upper \\
\hline Attitude & 1.482 & 0.559 & 7.033 & 1 & 0.008 & 4.4 & 1.4 & 13.1 \\
\hline
\end{tabular}

$\mathrm{SE}=$ standard error $\mathrm{CI}=$ confidence interval

of information on HIV/AIDS prevention (49.2\%), and most respondents exhibited positive behavior toward HIV/AIDS prevention (52.5\%).

The results of the study showed that there was no significant relationship between sex and adolescent behavior regarding HIV/AIDS prevention. These results support the study conducted by Aung Zaw et al, ${ }^{13}$ who state that there is no significant relationship between sex and knowledge, attitude, practice $(\mathrm{p}$-value $=0.212)$. Based on the statistical data, sex and adolescent behavior regarding prevention of HIV/AIDS had no correlation. However, this study showed that there was a comparison between the sexes with positive behavior regarding the prevention of HIV/AIDS. The results showed that female respondents had the most positive behavior regarding HIV/AIDS prevention, reaching 20 (57.14\%) respondents. A total of 13 male respondents $(54.16 \%)$ showed negative behaviors on HIV/AIDS prevention. This study found that women were more likely to display positive behavior than men. Putra stated that men are three times more likely to engage in sexual behavior compared to women. ${ }^{17}$ Fisher's study results, in Putra found that male adolescents tended to think more about sexual matters than females. ${ }^{17}$ According to Mahmudah, men have a greater likelihood of engaging in risky sexual behavior than women. ${ }^{18}$ Sofni LM, ${ }^{19}$ explained that this is because women were more concerned about their health than men.

The Chi-square test results of the education variables showed that there was no significant relationship between education majors and adolescent behavior regarding HIV/AIDS prevention. The results of this study support the study conducted by Faradina, stating that there is no significant relationship between the education level and the behavior of preventing HIV/AIDS transmission by reproductive-age People Live With HIV/AIDS (PLWHA) in Singkawang City in 2013 (pvalue $=0.156) .{ }^{20}$ This study also presents similar results to those of Rahmawan, who stated that there were no significant differences between the interests of natural science students and social studies classes and learning physical, sports, and health education at Sidoarjo 1 State Senior High School. Based on differences in the perspectives between natural science students and social studies students, physical education can be used as a means to support students to develop scientific and natural ways of thinking. ${ }^{21}$ This study showed that there was no significant relationship between education majors with regards to HIV/AIDS prevention behavior. The number of science-major respondents showing their behavior on HIV/AIDS prevention is $18(56.25 \%)$ ). It is higher than the number of social sciences students showing their behavior on HIV/AIDS prevention, which was only $13(48.15 \%)$ respondents.

The Chi-square test results showed that there was a significant relationship between the knowledge level and adolescent behavior regarding HIV/AIDS prevention. Most respondents had a sufficient knowledge level of HIV/AIDS prevention. A total of 24 respondents $(55.81 \%)$ showed negative behavior regarding HIV/AIDS prevention. The highest percentage of respondents with a positive attitude was at the good knowledge level at 12 respondents $(75 \%)$. Respondents with a negative attitude with sufficient knowledge level numbered $24(55.81 \%)$. This happens because most respondents possessed inadequate knowledge about symptoms, and transmission, and espoused myths about HIV/AIDS. This study supports the study conducted by Tampubolon, ${ }^{22}$ stating that there is a relationship of knowledge with the prevention of HIV/AIDS ( -value = 0.042). ${ }^{22}$ In addition, this study supports the study of Noorhidayah, ${ }^{1}$ stating that there is a relationship between knowledge and efforts to prevent HIV/AIDS in adolescent street communities in Banjarmasin in 2016 ( $p$-value $=0,000)$. Aung, et al state that a good level of knowledge reduces negative behavior and negative attitudes about HIV infection. ${ }^{13}$ In addition, the study by Singale states that the better one's knowledge about HIV/AIDS, the better the preventive measures one takes, and vice versa. ${ }^{23}$ These data reinforce the results of the study because respondents who had a good knowledge also had a positive attitude toward the prevention of HIV/AIDS. On the other hand, respondents with sufficient knowledge showed negative behaviors in the prevention of HIV/AIDS. In short, positive and negative behaviors are strongly influenced by the level of 
knowledge. Poor understanding of the transmission of Sexually Transmitted Infections (STIs), HIV, and AIDS will have an impact on the behavior of STI prevention, HIV, and AIDS. ${ }^{24}$

Attitude is one of the factors that influences adolescent behavior regarding HIV/AIDS prevention. The results of the Chi-square test showed that there was a significant relationship between attitudes on HIV/AIDS prevention and adolescent behavior on HIV/AIDS prevention. Most respondents (22; 68.75\%) had a supportive attitude toward the prevention of HIV/AIDS and positive behavior regarding HIV/AIDS prevention. A total of 9 respondents $(33.33 \%)$ had an unsupportive attitude but positive behavior on HIV/AIDS prevention. This study is similar to the study conducted by Tampubolon, stating that there is a relationship between attitudes with the prevention of HIV/AIDS ( $\mathrm{p}$-value $=0.005) .{ }^{22}$ In addition, this study also supports Noorhidayah in stating that there is a relationship between attitudes and HIV/AIDS prevention efforts among adolescent street communities in Banjarmasin in 2016 (p-value = 0,000).

Study by Aung Zaw et al, ${ }^{13}$ state that respondents with a good level of positive attitude have a good level of practice. Those who have a bad positive attitude show bad practice. This also shows a statistically significant relationship between positive attitudes and practice ( $\mathrm{p}$ value $=0,000)$. This supports Morton et al, in Wulandari, ${ }^{25}$ who state that knowledge is a mediator of behavioral changes and a variables that directly affects behavior is attitude. Notoadmodjo in Berliana states in the determination of attitude, knowledge, thoughts, beliefs, and emotions play an important role. ${ }^{26}$ Burhan states that attitudes directly influence behavior. More behavioral predispositions will only be discussed if conditions and circumstances allow. ${ }^{27}$

This study showed that 10 respondents $(31.25 \%)$ possessed a supportive attitude on the prevention of HIV/AIDS with negative behavior. A total of 18 respondents $(66.67 \%)$ had unsupportive attitudes and negative behavior on HIV/AIDS prevention. This proves that someone with a supportive attitude of HIV/AIDS prevention will have a more positive attitude on HIV/AIDS prevention, and vice versa.

Another factor that influences adolescent behavior toward HIV/AIDS prevention is information source. The Chi-square test results showed that there was no significant relationship between sources of information on HIV/AIDS prevention and adolescent behavior on the HIV/AIDS prevention. This study strengthens the study by Wulandari who explained that the effect of information exposure does not have a significant relationship with behavior on the prevention of Sexually Transmission Disease (STDs) and HIV/AIDS (p-value =
$0.141) .25$ In addition, this study also agrees with Wenny, who states that there is no relationship between HIV/AIDS information access and HIV/AIDS prevention behavior in the study on the users of injected drugs in Pontianak, West Kalimantan. ${ }^{28}$ Despite having good knowledge, someone tends to risk contacting HIV. This happens because of a lack of awareness and fear of being infected by the HIV/AIDS virus. ${ }^{1}$ Swati states that mass media is also a trusted source of information for students. It is important that the message they receive through this mode, whether in the form of a public awareness program, film, or documentary, should be credible and comprehensive to avoid developing misunderstandings. ${ }^{29}$ Duffy, in Zahroh, states that the media has long been used to provide information related to HIV/AIDS with the aim at increasing knowledge, attitudes, and behavior. In addition, information about HIV/AIDS through the media also has an impact on reducing stigma on ODHA even though this does not happen in all countries or communities. ${ }^{30}$

In this study, respondents with a positive attitude on the HIV/AIDS prevention and access electronic media as a source of information are $16(55.17 \%)$ respondents. The majority of respondents $(13 ; 44.83 \%)$ had negative behavior regarding HIV/AIDS prevention and use electronic media as a source of information. A total of 26 respondents accessed information sources through the internet and 3 from television. This happens due to the lack of comprehensive source information or misunderstanding in receiving information. Searching for and receiving information through electronic media or other sources must be conducted through credible sources that give verified information.

In general, the factor that influences adolescent behavior on the HIV/AIDS prevention based on the results of multivariate test analysis with statistically significant variables is attitude with $\mathrm{p}$-value $=0.008$; PR $=4.4 ; 95 \% \mathrm{CI}=1.4-13.1$. Adolescents with a supportive attitude on the prevention of HIV/AIDS will be 4.4 times more likely to develop positive behavior than adolescents with an unsupportive attitude. This supports Morton, et $a l$ in Wulandari, who states that knowledge is a mediator of behavioral change and variables that directly influence behavior are attitudes. ${ }^{25}$

\section{Conclusion}

Most respondents in this study who are females from the natural science majors, have sufficient knowledge level, but still have insufficient knowledge about symptoms, modes of transmission, and myths about HIV/AIDS. Students have supportive attitude toward HIV/AIDS prevention. The most extensive source of information found in this study comes from electronic media, such as television and the internet. Students 
mostly have positive behavior toward prevention of HIV/AIDS. There is no relationship between sex, education major, or information sources with adolescent behavior on HIV/AIDS prevention. Significant relationships were level of knowledge and attitudes with adolescent behavior on the prevention of HIV/AIDS. The factors that have the strongest influence on adolescent behavior regarding the prevention of HIV/AIDS is attitude. Knowledge is a mediator of behavioral change and the variable that directly influences behavior is attitude. Someone who is supportive of HIV/AIDS prevention will display more positive behavior toward HIV/AIDS prevention.

\section{References}

1. Noorhidayah, Asrinawaty, Perdana. Hubungan pengetahuan, sikap, dan sumber informasi dengan upaya pencegahan HIV/AIDS pada remaja komunitas anak jalanan di banjarmasin tahun 2016. Jurnal Dinamika Kesehatan, 2016; 7 (1): 278-82 Vol.7 No.1 Juli 2016. 2016; 272-282.

2. Tampi D, Grace DK, Gustaaf EAA. Hubungan pengetahuan, sikap dengan tindakan pencegahan HIV/AIDS pada siswa SMA Manado International School. Jurnal Kedokteran Komunitas dan Tropik, 2013; 1 (4): $140-145$

3. Prawiroharjo S. Ilmu kebidanan. Ed 4. Jakarta: PT. Bina Pustaka; 2010. p. 932.

4. World Health Organization. People living with HIV. Geneva: WHO; 2016. p. 1-4.

5. World Health Organization. Global situation and trends [Internet]. 2016. Available from: http://www.who.int/gho /hiv/en/.

6. United Nations Emergency Children's Fund. HIV/AIDS continues to stalk children and adolescents [Internet]. 2016. Available from: https://www.unicef.org /media/media91908.html/.

7. Direktorat Jendral Pengendalian Penyakit. Laporan situasi perkembangan HIV/AIDS dan PIMS di Indonesia Oktober-Desember 2016; 2016. p. 8-20.

8. Dinas Kesehatan Daerah Istimewa Yogyakarta. Profil kesehatan Daerah Istimewa Yogyakarta tahun 2016. Yogyakarta: Dinas Kesehatan DIY; 2016. p. 36-39.

9. Pusat Promosi Kesehatan Kementerian Kesehatan RI. Buku petunjuk penggunaan media KIE versi pelajar aku bangga aku tahu; 2012. p. 7: 64-67.

10. Stalker P. Millennium development goals; 2008. p. 7.

11. Kementerian Perencanaan Pembangunan Nasional/Bappenas. Terjemahan tujuan dan target global tujuan pembangunan berkelanjutan (TPB)/sustainable development goals (SDG's). Kementerian Perencanaan Pembangunan Nasional/BAPPENAS; 2017. p. 13-14.

12. Setyarini AI, Titisari I, Ramadhania PA. Hubungan pengetahuan remaja tentang HIV/AIDS dengan sikap pencegahan HIV/AIDS di SMA Negeri 1 Gurah Kabupaten Kediri. Jurnal Ilmu Kesehatan, 2016; 4 (2); 25-33.

13. Aung Z, Anisah, Wee KW, Kyin H, Than N, Kamil, et al. Cross sectional study of knowledge, attitude, and practice on HIV infection among secondary school students in Kuala Terengganu. International Journal of Medicine and Medical Sciences, 2013; 4 (4); 1335-1346.

14. Ariani PD, Hargono A. Analisis hubungan antara pengetahuan, sikap dengan tindakan berdasarkan indikator surveilans perilaku HIV/AIDS pada wanita pekerja seks (studi penelitian di Klinik IMS Puskesmas Putat Jaya Surabaya). Jurnal Departemen Epidemiologi FKM Unair. 2013. URL: http://repository.unair.ac.id/23634/

15. Rahman RTA, Esti Y. Faktor-faktor yang mempengaruhi perilaku pencegahan HIV/AIDS pada remaja. Jurnal Dinamika Kesehatan, 2014; 13 (3); 80-93.

16. Lestary H, Sugiharti. Perilaku berisiko remaja di Indonesia menurut survey kesehatan reproduksi remaja Indonesia (SKRRI) tahun 2007. Jurnal Kesehatan Reproduksi, 20011; 1 (3): 136-44.

17. Putra IGNE, Pradnyani PE, Artini NNA, Astiti NLEP. Faktor yang berhubungan dengan perilaku seksual pada remaja yang berpacaran di Kota Denpasar. Jurnal Kesehatan Masyarakat Andalas, 2017; 11 (2); 75-83.

18. Mahmudah, Yaunin Y, Lestari Y. Faktor-faktor yang berhubungan dengan perilaku seksual remaja di Kota Padang. Jurnal Kesehatan Andalas, 2016; 5 (2): 448-55.

19. Sofni LM, Dewi YI, Novayelinda R. Perbandingan pengetahuan dan sikap antara remaja putra dan remaja putri tentang tindakan pencegahan HIV/AIDS. Jurnal Online Mahasiswa Universitas Riau, 2015; 2 (2): 1214-49.

20. Faradina A, Saleh I, Taufik M. Faktor yang berhubungan dengan perilaku pencegahan penularan HIV/AIDS oleh ODHA wanita usia reproduksi di Kota Singkawang tahun 2013. Jurnal Mahasiswa dan Penelitian Kesehatan. 2013; 1(1): 147-54.

21. Rahmawan EF, Hidayat T. Perbandingan minat kelas IPA dan kelas IPS terhadap pembelajaran pendidikan jasmani, olahraga, dan kesehatan di SMA. Jurnal Pendidikan Olahraga dan Kesehatan, 2013; 01 (01); 107 112.

22. Tampubolon D, Siregar R, Simanjuntak GV. Hubungan pengetahuan dan sikap siswa tentang HIV/AIDS dengan tindakan pencegahan penularan HIV/AIDS di SMA Negeri 12 Helvetia Medan tahun 2015. 2015. https://www.academia.edu/32017075

23. Lastianti S. Hubungan antara pengetahuan dan sikap tentang HIV/AIDS dengan tindakan pencegahan HIV/AIDS pada Siswa SMK Negeri 3 Tahuna. Jurnal Universitas Sam Ratulangi Manado. 2012; 111.

24. Purnamawati D. Perilaku pencegahan penyakit menular seksual di kalangan wanita pekerja seksual langsung. Kemas: Jurnal Kesehatan Masyarakat Nasional. 2013; 7 (11): 514-21.

25. Wulandari S. Hubungan pengetahuan, sikap, dan perilaku pencegahan penyakit menular seksual (PMS) dan HIV/AIDS dengan pemanfaatan pusat informasi konseling remaja (PIK-R) pada remaja SMKN Tandun Kabupaten Rokan Hulu. Jurnal Maternity and Neonatal, 2015; 2 (2); $10-23$.

26. Situmeang B, Syarif S, Mahkota R. Hubungan pengetahuan HIV/AIDS dengan stigma terhadap orang dengan HIV/AIDS di kalangan remaja 15-19 tahun di Indonesia (analisis data SDKI tahun 2012). Jurnal Epidemiologi Kesehatan Indonesia. 2017; 1 (2): 35-43.

27. Burhan R. Pemanfaatan pelayanan kesehatan oleh perempuan terinfeksi HIV/AIDS. Kesmas: Jurnal Kesehatan Masyarakat Nasional. 2013; 8 (1): 33-8.

28. Chartika W, Hernawan AD, Ridha A. Hubungan antara pengetahuan, sikap, akses informasi HIV/AIDS dan dukungan dengan perilaku 
pencegahan HIV/AIDS pada pengguna napza suntik di Kota Pontianak. Jurnal Mahasiswa dan Penelitian Kesehatan-JuManTik. 2013; 163-72.

29. Swati A, Sushma B. Knowledge, attitude, and sources of information for increasing awareness about HIV/AIDS among college students. Healthline Journal of Indian Association of Preventive and Social
Medicine. 2015; 4 (4): 50-7.

30. Shaluhiyah Z, Mustofa SB, Widjanarko B. Stigma masyarakkat terhadap orang dengan HIV/AIDS. Kesmas: Jurnal Kesehatan Masyarakat Nasional. 2015; 9 (4): 303-09. 